\title{
Andragogy: Process and Context Based (PCB) Model for Adult Learners
}

\author{
Jiban Khadka, $\mathrm{PhD}$ \\ Associate Professor of Education, Faculty of Social Sciences and Education, Nepal Open University
}

\begin{abstract}
The literature reports that andragogy is methods of teaching for adult learning that basically differs from pedagogy in terms of learning, focus, power and control, learning, learning design, development. The andragogical models focus on the process rather than content, and the process concerns with how the procedures and resources help the learners. However, they have focused less on the role of environment (context) in the implementation of the models where the context includes several factors such as enabling, empowering and engaging. This paper has described a blended model that might be implied in higher education institutions. The proposed model called Process and Context based (PCB) model for adult learners, includes both process and context. Experience, action and reflections are the primary elements of the process whereas enabling, engaging and empowering are the components of a conducive environment for a learning organization.
\end{abstract}

Keywords: Andragogy, Adult Learners, Learning, Experience, Environment

DOI: $10.7176 / \mathrm{JAAS} / 63-04$

Publication date: April $30^{\text {th }} 2020$

\section{Introduction}

Andragogy is methods of teaching for adult learning. It is defined as a set of core learning principles that is applied for guiding adult learning, and it focuses on process model rather than content models (Knowles, Holton III \& Swanson, 2015). This basically differs from pedagogy in terms of learning, focus, power and control, learning, learning design, development (Crawford, Wallace \& White, 2018). However, Mueller's (1982) study did not find the difference between andragogy and pedagogy as both training (adult education) and education (youth education) programs were operated from the same philosophical biases, purposes, teaching methods and evaluation techniques (p. 47). Many Scholars like Foley (2004), Schon (1983), Kolb (2015) and others have developed the adult learning models. They focus on different aspects of learning process such as experience, action, reflection and so on. However, they have focused less on the role of environment (context) in the implementation of the models. The context related factors such as enabling, empowering or engaging are over sighted and not included as the dimensions of the adult learning models. How can the different components of learning process and environment be adopted in a model for adult education? How does the model work in higher education in a holistic approach?

In this reviewed paper, an attempt has been made to answer the above questions from various sources of literature such as theoretical and empirical studies. First, the author describes the study contexts where a teacher might fit the teaching strategy: andragogy. Second, the study of andragogical models would be the subjects of review. Finally, the author proposes a model including process and environment that probably fits the traditional or virtual mode of higher education.

\section{Context Overview}

Nepal Open University has been providing distance and open mode of education to the students across the country since 2018. They have got opportunity of higher education from their work place or from this home. In general, after the completion of school education, completion of $12^{\text {th }}$ grade, they start their job in their home town or outside it. When they need promotion, are financially capable, settle their family, might have passion/need for further study, then, they join university. They are in the state of having a lot experience that may or may not be relevant to their higher education. Some courses in the higher education are similar to their under(graduate) level, and some may be different. They complete their degree through conventional mode, and now, they get through online mode. So, the mode of course delivery has been transformed from F2F to online. The activities such as presentation, assignment, participation all are done through virtual mode or computer-mediated source. In this aspect, the learners are little literate in digital technology.

When they joined the university, in an observation of a period of two semesters in the university, in one hand some of the post graduate students of this university requests for regular presence of teachers, regular support in computer-based activities, even regular lecture on the course contents like to F2F class, and some request for democratic environment, students' role and teacher's facilitation rather than lecture. The authority always suggests the faculties to give them respect as they are adult students, socially respected and recognized persons. They are socially responsible; they know their positions; and they need just guidance and facilitation. In this context, some students highly depend on the teachers and expects teacher's regular classes like in schools, and some not. In this 
dilemma, what is the teacher's role? What model of andragogy is effective? They are mature by age and experience to some extent, does a single model of andragogy work for all types of post-graduate students? In this paper, an attempt is made to analyze some models of adult education, and propose a model for adult learners in both online and F2F mode of learning.

\section{Andragogy: Adult Education}

The teaching strategy used for adult education is defined as andragogy. Knowles et al. (2015) defined andragogy, coined this term by Yugoslavian adult Educator-Dusan Savicevic in 1967, as the integrated conceptual framework of adult learning. They define it as a theory for adult learning how they learn. In the words of Crawford et al. (2018), it has been conventionally viewed as the learning styles of adults where they manage their knowledge, they have more real experience, they understand in their own ways, may be in different and new ways. Foley (2004, chapter 1) observes the adult education through the lens of interpretivism and criticalism with the belief that "meanings are individually constructed and focuses on the adult learners to enable them to become proficient by 'learning how to learn'" (p. 13). Further, she interprets people see the world differently, and the understandings are both subjective and socially constructed, and the approach of adult education depends on self-direction and reflection-on-action in spiral order. In this way, Foley (2004) emphasizes on the pluralistic and contextual approach in adult learning while designing programs, teaching and assessing the performance.

From the brief review of the literature on andragogy, it is found that adult learning is subjective, individual, socially constructed, self-direction and reflection on action. However, what is the adult learning community? What are the basic characteristics of adult learners? What are the major dimensions of andragogy (adult learning)? What are the stages of adult learning? How are they applied in adult learning process? These issues will be the focus of the following sections:

Eckel \& King (2004) states that in the context of America, one of the characteristics is found in adult learners: age 25 or older, delayed entry into higher education after school education, did not earn a traditional high school diploma, are married, attend part time, work full time, or have children (p. 7). Many scholars of andragogy like Crawford et al. (2018), Knowles et al. (2015), and Blanchard-Fields and Kalinauskas (2009) have highlighted different characteristics of an adult learners. Here, Kuhne (2016) summarized some important characteristics of adult learners in the course "Introduction to Adult Education" offered through Penn State's World Campus. These characteristics are related to the adult learning. As he mentioned, they are desired to tend to be self-directed and take control over learning environment, they want to link their learning to their prior learning experience as they have long experience. They choose their learning as per their interests and needs so that they are motivating in learning. They believe in practicality of their learning rather than memorizing and rotting theory. They want immediate use of the knowledge in their practical life so they are pragmatic in learning. They are busy in their job, family or social activities, rather than study. This situation tends to push them being secondary role of adults in learning. They have the constraints of time and energy, and they may not be able to manage time and efforts in learning. Further, adults' school background is also contributing factor to their learning, sometimes, for some learners, they do not have enough confidence level due to poor school background. They have developed certain set of beliefs throughout the days before re-joining the college or university, these embedded set of beliefs or experiences resist them to accept the changing both content and context for the learning. There is more diversity in the learners that necessitate more time for their engagement in sharing their experiences among the diverse learners. The pace of learning is affected by aging of adult learners rather than their intelligence level. This inverse relation between age and pace of learning might be discouraging to get a deeper and more integrative level of learning. (Crawford et al., 2018; Knowles et al., 2015; Blanchard-Fields \& Kalinauskas, 2009). Considering the characteristics of adult learners, different models/frameworks of adult learning are found in the literature.

\subsection{Models for Adult Learning}

Many scholars' models, for example, Foley's (2004) framework of adult education, Knowles, Holton \& Swanson's (1998) andragogy of practice, Grow's (1996) self-directed learning model, Bateson's (1972) transformational theory of adult learning, Schon's $(1983,1987)$ reflective models and others are developed that have enriched the adult learning strategy. In this paper, the following models of adult learning are analyzed as they are useful in one and the way other.

Foley's (2004) Conceptual Framework. Foley's (2004) conceptual framework of adult learning emphasizes the use of theory in the adults' practical life. Because, adult learners concern with the practical use of the theories, they engage in practice and reflection on it. He considers four elements while developing framework for adult learners. They are context, values, techniques and strategy. First, context of adult learner is a crucial element to be considered. It is also called historical dimension that includes different aspects of learners such as learners' feeling and thoughts, personal, interpersonal, institutional or social context, and socio-economic and political concerns of learners. Second, value system is one of the important dimensions of the framework. This dimension concerns with the values the learners give on their actions. Why they are going to do the action? Are they valuable for their practical lives? Are they meaningful and applicable at present life? The adult educators should consider these 
questions while preparing model of the learners. The third considerable element is techniques. There are many more technical aspects such as program development, catering of adult skills, managing group work and so on. Adult educator should technically sound and proficient in designing and operating the adult education framework. The final element is strategy that is setting strategy. There is necessary to make plan to achieve the short-term and long-term goals. The goals guide the educators to implement the programs to meet the standards keeping on track of adult education (Foley, 2004).

Schon's (1983) Reflective Model. This model of adult learning emphasizes on the reflective mode of program designing. The process of model design proceeds towards the order of plan, action and reflection, and then, new plan in cycle or spiral path. In this model, an educator can prepare a plan for adult learners with considering what to teach, how to teach, why to teach and how to assess the outcomes. Then, he/she goes in action or implement the plan for facilitating/teaching the learners. During the implementation stage, there will be the act of 'reflection-inaction' in which educator use their experience in the action or reflect on their experience gained in earlier days. Then, next stage is 'reflection-on-action' which is tested by hypothetico-deductive system that comes true for positivist paradigm (p. 33).

As stated in Schon's (1983), during the course of problem solving, there are complexity, uncertainty, instability, uniqueness, and value-conflict where knowing-in-action is important. Moreover, this model also suggests to think about doing something while doing it in the midst of a performance. There a learner can improvise his act or action to solve the problems or while engaging in a planned action combining, and recombining a set of figures within the schema. This practice helps a learner to understand a theory in practice and to develop higher order of learning.

Boud, Keogh \& Walke's (2005) Reflection: Turning Experience into Learning. Likely to Schon's (1983) model, Boud, Keogh \& Walke's (2005) 'Reflection: Turning Experience into Learning' (p. 7) is a matter for adult learner. The adult learners have long experience but it does not mean that the experience is sufficient to learning new thing. In their words, they are half digested in work experience, and may not be appropriate for academically oriented learning. They raised the following questions that are relevant while someone turns experience into practice:

What is it that turns experience into learning?

What specifically enables learners to gain the maximum benefit from the situations they find themselves in?

How can they apply their experiences in new contexts?

Why can some learners appear to benefit more than others?

They suggest that adults' experience is to be considered while designing learning program. The experience is applicable in learning activities, for example, the project work, practical work, on-the-job training, field study, internships, clinical training, pastoral work, educational gaming and simulation and other forms of experiential learning.

Kolb's (2015) Experiential Learning Cycle. Kolb (2015) state different experiential learning model that are recommended for higher education. This experience-based education is popular methods in higher level of education, and has become the method of choice for non-traditional learners, for example, minorities, the poor, and mature adults (p. 3). John Dewey, Kurt Lewin and Jean Piaget were the well-known scholars who contributed to experiential learning theory and highlighted Kolb's research on this method of learning.

In K. Lewin's (1951) experiential learning theory, it is described that learning is supposed to be the life-long learning process that critically bridges among work, education and personal development. This method helps learners for deep learning which means to connect the classroom to real world. In his experiential learning process, four functions are highlighted, and they are experience, reflection, generalization and application. In the continuum of this theory, Dewey's ideas on 'Experiential Learning', learning is very much similar to Lewin's theory. It defined as a dialectical process that integrates experience, observation and action, and finally, the consequences should be linked to the learners' desire and impulses to acquire moving force (Kolb, 2015, p. 33).

Kolb (2015) summarized that experiential learning is viewed as a dialectical process between action and reflection, and experience and abstraction. The updated model of experiential learning is presented in figure 1. 
Figure 1. The Experiential Learning Cycle

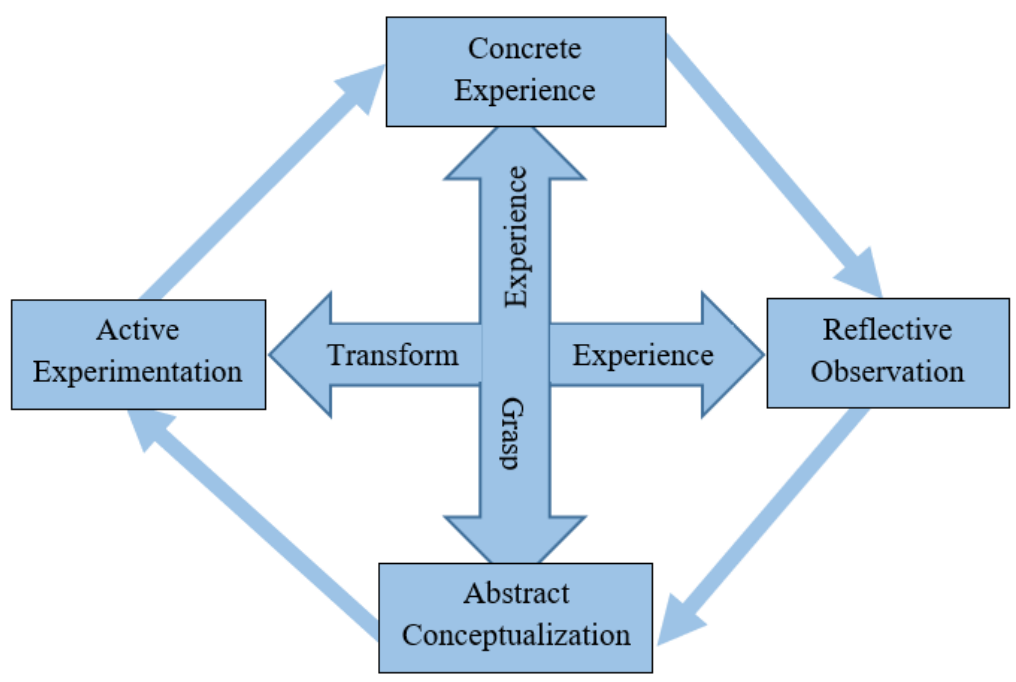

Source: D. A. Kolb's (2015) 'The Experiential Learning Cycle'

As presented in figure 1, it is recursive process in which there is objective or concrete experience that is the basis for evaluative/reflective observation. From reflective observation, someone reaches the level of generalization of those reflection. The end of cycle is the application level of the generalized ideas or learning which avenues to transform the experience in higher level of new learning.

\section{Learning Context for Adult Learners}

Learning environment is a highly instrumental factor for learning. Kausar, Kiyani, \& Suleman (2017) revealed that classroom environment such as well-managed and vibrant classroom environment had a positive effect on the academic achievement of students in school level education. Nuhu (2015) also investigated that school building, class with adequate furniture, class with small class population and the use of instructional materials had positive impact on the performance of students in Junior Secondary schools. Similarly, in virtual class situation, Barker and Gossman's (2013) study showed that use of virtual learning environment (VLE) improved the students' learning and it motivated them to learn. They suggested to give attention in promoting the use of VLE to enhance learning. Alves, Miranda and Morais (2017) state that online students have different approaches such as uses of the VLE, click to learn, read a file, take notes, print or save in the computer for further offline use. They conclude from their study on the students of a public higher education institution that showed relatively positive indicators regarding students' access to a virtual learning environment and the relation between such access and their performance. From the study of a few number of empirical researches on the impact of learning environment on students' performance, they are true for justifying positive relation between these two variables: learning environment and performance. Even more, the results are true for both online and F2F learning, and youth and adult learning contexts.

As stated by Foley (2004) in chapter 1, adult educators have to think about the learners that when the learners do things, they are engaged in practice; then they think about their practice, finally they reflect and theorize it. For a conducive learning environment, it is essential for learners to be enabled, empowered and engaged (3E) in a learning organization. The $3 \mathrm{E}$ is mostly used in business organization for the efficient and effectiveness of employees' performance. Despite this, how learners involve in learning process through the 3E-management system might be relevant to discuss here.

Enabling Factor. According to Cambridge Dictionary, 'Enable' mean 'making something possible or easier'. Then, it is possible when people get access to the tools of powers and help to utilize their potential. Enabling factor concerns with the people to have access to resources, opportunity or authority to do something. In other words, funding and budget, human resource's capabilities and capacities for new technologies are enabling factors. Adler and Borys (1996) diagrammatically present the four types of organization culture (Organic, mechanistic, autocratic and high bureaucratic) which occur when there is practice of 'Degree of Formalization' at high or low in enabling or coercive environment. The practice of high degree of formalization in enabling environment tends to be highly bureaucratic organization, at low degree of formalization in enabling environment, it tends to be organic organization, at low degree of formalization in coercive environment, the organization tends to be autocratic, and at high degree of formalization in coercive environment, it tends to be mechanistic organization. Out of four types of organization culture, minimum practice of formalization with enabled environment is found effective. Alston and Tippett (2009) noted that the technology-based organizations which moved from mechanistic toward organic 
became more productive, successful, and high performing organizations (as cited in Jewczyn, 2010). In educational context, the practice of acts, regulation, curriculum and local provisions might determine the degree of formalization, likewise, the institution facilities and activities might determine the enabling or coercive environment. However, this is not empirically tested in the education organization.

Empowering Factor. Empowering refers to equip someone by powers that help to mobilize their skills and resources. Bonk and Ke Zang (2008) presents R2D2 (Read, Reflect, Display and Do) model that emphasizes to empower both e-learners and e-instructors. The model suggests e-learners to integrate various types of learning activities with appropriate technology. Likewise, Tohidi and Jabbari (2012) cite four types of empowerment: sense of competence, sense of being effective, sense of being valuable, autonomy, and Trust. Busara (2016) includes three types of empowerment in his study. They are training employees, creating a culture of allowing employees to give input and have control of their work, and giving employee access to information and providing feedback. So, there are various types of empowerment practices. However, the practice of empowering people tends to be engaged in their work that ultimately contributes to better organizational performance. In business organization, performance is mostly measured in terms of profit whereas in education organization, it is measured in terms of student learning achievement. The empowering people so far is strongly correlated to organizational performance (Busara, 2016).

Engaging Factor. Engaging is simply known as the employees or teachers, students' involvement in work/learning. They are involved in the learning process and it helps them become efficient and effective. There are various components of engagement in working activities. Fredricks, Blumenfeld and Paris (2004) identified several components such as behavioral, emotional/psychological, cognitive, and academic engagement of students in learning) (as cited in Lee, 2014). Similarly, Lee (2014) assessed behavioral engagement and emotional engagement in learning that were revealed as significant predictor of reading performance. He further suggests the school managers, administrators and teachers to pay attention to students' engagement to enhance their learning.

The Speak Up National Research Project (2010) reports about the learning that is enabled, empowered and engaged to transform education where use of emerging technology is imperative. Besides creating engaging and enabling institutional environment, people's engagement is most essential component in learning process. The learning environment equipped with these three factors (3E) may enhance the adult education through any models or frameworks for adult education aforementioned. How these factors are essential? Do they contribute to implement generic models of adult learning? The following section illuminates a holistic model for adult learning that is proposed for adult education.

\section{Process and Context Based (PCB) Model for Adult Learners}

Many educationists or practitioners like Lee (2014), Tohidi and Jabbari (2012), Bonk and Ke Zang (2008), Fredricks et al. (2004), Adler and Borys (1996) and many others focus on the organizational/school environment for enhancing the performance (learning achievement). Their studies focused less on the process of learning or operational management. On other hand, Schon (1983), Foley (2004), Boud et al. (2005), Kolb (2015) and the other scholars focused on the process of learning rather than environment. However, both streams of scholars do not miss the discussion on the role of both process and environment of learning. They analogically describe the process of learning and the environment for learning one way or another.

The following figure 2, PCB model, is the summarized model for the adult learners that includes both process and environment. This model is a holistic in the sense that managers, administrators, educators, teachers and students need to involve for its effective implementation. 
Figure 2. Process and Environment Based (PCB) Model for Adult Learners

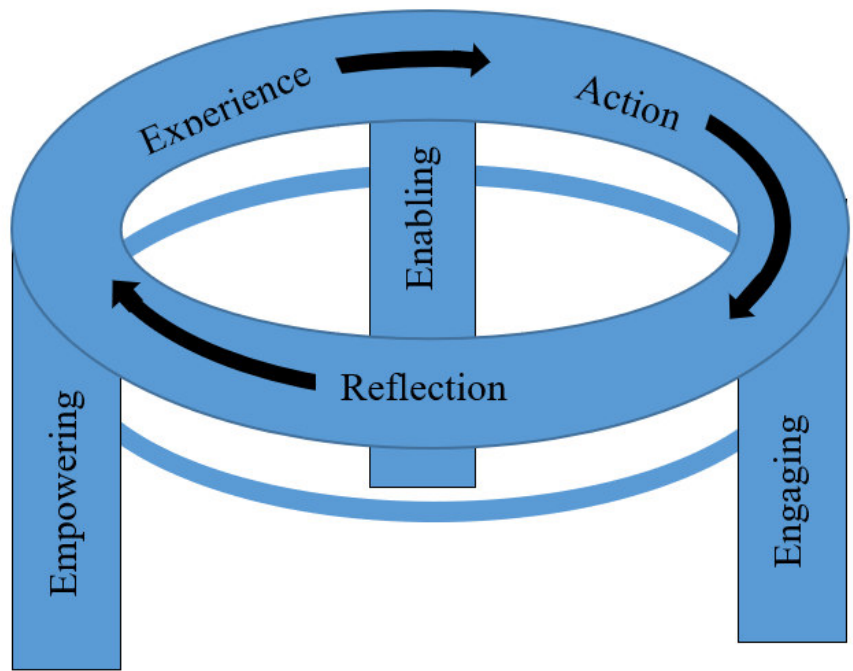

Source: Concept cited from Kilb, 2015; Boud et al., 2005; Schon, 1983 and others

In the figure 2 PCB model, the process in the circle that may be in spiral, includes three components: experience, action and reflection. Experience is mostly considered component of adult learners that may be starting point in new course of learning in the university. They experience from their job, social, cultural, economic or political activities before they join the the higher education institutions. In experiential learning, Kolb (2015) called it progressive learning that is one of the core concerns for adult learning. Highlighting the role of experience in adult learning, Henschke (2009) says that

Andragogy as the place and process where adult learners (average age of 40) are involved in the learning process, and are encouraged to bring their considerable life and work experience into the discussions. Thus, adults often get better jobs, build their self-esteem and serve as role models to family and friends to their great benefit.

Pearson and Smith (1994, chapter 4) state that in old age, experience is supposed to be the best teacher and still true for some extent. In their words, they experience in earlier stages through different sources, and that help them resolve the problems.

In the cycle, the next stage of learning is action a learner involves in their day-to-day life or in learning process. Schon (1984) states 'reflection-in-action' necessarily involves experiment which is process of learning. They use their experience during the course of action that can help to solve the problems. This event occurs in ongoing process of a learning activity. Fenwick and Tennant (2004) also contends that meaningful participation in everyday activity is the focus of learning and knowledge outcome (Pearson \& Smith, 1994). In both stages: experience and action, learner's experience is accompanied.

The third stage of the cycle is reflection that involves both grasping and transformation of knowledge at higher level. This is another higher level of learning that is retrospective. Fenwick and Tennant (2004) state learning as reflection that is an active constructor of knowledge, creating new meanings and realities. Similarly, Pearson and Smith (1994) state people learn from reflection when they engage in an activity that may be part of on-the-job training, in-service education, work-experience and so on. They compare and contrast the present experience with past experience, and critically reflect on their action or practice that transforms at higher level of learning.

In the figure 2, three pillars: Enabling, Engaging and Engaging underpin the reflective cycle of learning process. In this concern, Knowles et al. (2015) contends that in advance, adult educators need to consider a set of elements for adult learning as follows:

(1) Prepare the adult learner;

(2) Manage a climate conducive to learning (richness and accessibility of resources - both material and human);

(3) Create mechanism for collaborative planning;

(4) Identify the needs for learning;

(5) Set program objectives

(6) Design a pattern of learning experiences;

(7) Conduct these learning activities,

(8) Evaluate the learning outcomes (p. 54)

The above eight elements are almost concerned with enabling and empowering the adult learners that create learning environment by engaging them in learning process. Engagement i.e. practice based on reflection-in-action 
is useful to the learners, and for this, conducive environment is required (Schon, 1983). While framing andragogy, Crawford et al. (2018) highlights the importance for adult learning in a way that includes self-direction, contentfocused, instructor-learner coordination, loop learning, cyclical learning design and competency development. Reflecting on his highlights, learners need to be empowered by creating enabling environment. Because, adult learners want to be self-directed rather than to be instructed by instructors. This is possible through the meaningful learning context where double-loop learning occurs. In double-loop learning, In Crawford et al.'s (2018) words, learners proactively engage in learnings together with the avoidance of mistakes, and looks meaning-making from deeper understanding.

The different models or empirical studies highlight the importance for creative learning environment. The learning environment, basically, engage, enable and empower the learners. The Speak Up National Research Project (2010) suggests educators to engage, enable and empower students through the use of these emerging technologies. It suggests to enable student use of the emerging technologies, engage them in rich, and compelling learning experiences in the classroom, empower both teachers and students to creatively envision the future and to provide opportunities of a new shared vision for learning.

\section{Conclusion}

The literature reports that andragogy concerns with the teaching strategy for adult learners. Many studies have discussed from different perspectives of andragogy such as process, philosophy and context of adult education. In adult education, teachers have faced several problems due to the learners' dual characteristics whether they are adult or youth learners in Nepali higher education. However, they are interested in practical and immediate use of knowledge and skills. They are likely to be self-directed and self-controlled in the premises of learning where the teachers' role of facilitating student is important for adult education. Their learning is more affected by their sharing experience due to the diverse characteristics of the adult learners. The diverse characteristics might be source of synergistic learning. Different models for adult education basically reflect two facets of adult education: process and context. First facet includes experience, action and reflection, and the second, environmental factors: enabling, empowering and engagement. The proposed PCB model for adult learners includes both facets: process and context of adult learning. This model might be effective for adult learners by the active participation of all stakeholders of higher education institutions.

\section{Reference}

Foley, G. (2004). Adult learning: Adult education and training in a global era. England: Open University Press.

Wilson, L. S. (2005). A test of andragogy in a post-secondary educational setting. LSU Doctoral Dissertations. 3916. Retrieved from https://digitalcommons.lsu.edu/gradschool dissertations/3916.

Knowles, M. K., Holton III, E. F. \& Swanson, R. A. (2015). The adult learner: The definitive classic in adult education and human resource development ( $8^{\text {th }}$ ed.). New York: Routledge.

Delahaye, B. L., Limerick, D. C. \& Hearn, G. (1994). The relationship between andragogical and pedagogical orientation and the implications for adult learning. Adult Education Quarterly 44(4): 187-200.

Crawford, C. M., Wallace, J. Y. \& White, S. A. (2018). Rethinking Pedagogy, Andragogy and Heutagogy. Academic exchange quarterly, 22 (4). ISSN 1096-1453.

Mueller, B. L. (1982). Andragogy and pedagogy: a comparison using a parallel pairs model (Doctoral dissertation). Graduate of College, University of Arizona, 300N Zeep Road, Ann Arbor.

Eckel, P. D. \& King, J. E. (2004). An overview of higher education in the United States: Diversity, access, and the role of the marketplace. Retrieved from https://ssl.acenet.edu/

Kuhne, G. (2016). ADTED 460 - Introduction to Adult Education (Course offered). Penn State's World Campus. Retrieved from http://ctle.hccs.edu/

Blanchard-Fields, F. \& Kalinauskas, A. S. (2009). Challenges for the current status of adult developmental theories: A new century of progress. In M. C. Smith, \& N. DeFrates-Densch (Eds.). Handbook of Research on Adult Learning and Development. UK: Routledge.

Knowles, M. K., Holton III, E. F. \& Swanson, R. A. (2005). The adult learner: The definitive classic in adult education and human resource development ( $6^{\text {th }}$ ed.). Butterworth-Heinemann: Elsevier Inc.

Bateson, G. (1972). Steps to an ecology of mind. New York: Chandler Publishing Company.

David C. M. Taylor \& Hamdy, H. (2013). Adult learning theories: Implications for learning and teaching in medical education: AMEE Guide No. 83, Medical Teacher, 35:11, e1561-e1572, DOI: 10.3109/0142159X.2013.828153.

Schon, D. (1983). The Reflective Practitioner: How professionals think in action. New York: Basic Books, Inc.

Kolb, D. A. (2015). Experiential learning: Experience as the source of learning and development (2 ${ }^{\text {nd }}$ ed.). USA: Pearson Education, Inc.

Boud, D., Keogh, R. \& Walke, D. (Eds.). (2005). Reflection: Turning experience into learning. USA: Routledge. 
Kausar, A., Kiyani, A. I. \& Suleman, Q. (2017). Effect of classroom environment on the academic achievement of secondary school students in the subject of Pakistan studies at secondary level in Rawalpindi District, Pakistan. Journal of Education and Practice, 8(24).

Nuhu, A. (2015). Impact of learning environment on the performance of students in social studies in junior secondary schools in Taraba state, Nigeria (Master Degree Dissertation). Faculty of Education, Ahmadu Bello University, Zaria, Nigeria.

Barker, J. \& Gossman, P. (2013). The learning impact of a virtual learning environment: students' views. Teacher Education Advancement Network Journal (TEAN), 5 (2), 19-38.

Alves, P. P., Miranda, L. \& Morais, C. (2017). The Influence of virtual learning environments in students' performance. Universal Journal of Educational Research 5(3): 517-527, 2017 http://www.hrpub.org DOI: 10.13189/ujer.2017.050325.

The Speak Up National Research Project (2011). The New 3 E's of education: Enabled, engaged, empowered: How today's educators are advancing a new vision for teaching and learning. Irvine: Project Tomorrow, 2011. Retrieved from https://tomorrow.org/speakup/pdfs/SU10_3EofEducation_Educators.pdf

Tohidi, H. \& Jabbari, M. M. (2012). The aspect of empowerment of human resources. Procedia-Social and behavioural sciences, 31 . Retrieved from https://www.sciencedirect.com/science/article/pii/S1877042811030795

Adler, P. S. \& Borys, B. (1996). Two types of bureaucracy: Enabling and coercive. Administrative science quarterly, $41 . \quad$ Retrieved from https://pdfs.semanticscholar.org/1c39/fbf8c17824e8d0bffecc95481509e81a7cf.pdf

Bonk, C. J. \& Ke Zang (2008). Empowering online learning 100+ activities for reading, reflecting, displaying, and doing. San Francisco: Jossey-Bass. Retrieved from file:///D:/1.\%20Jiban-1/4.Research\%20Articles2076/Pedagogy-andragogy-heutagogy/Bonk-Zhang\%20-\%202008Empowering\%20Online\%20Learning_\%20100+\%20Activities.pdf

Busara, G. C. (2016). Impact of employees empowerment on organization performance: A case study of government procurement service agency (Master Degree Dissertation). Master of Project Management of the Open University of Tanzania.

Lee, J.S. (2014). The relationship between student engagement and academic performance: Is it a myth or reality? The Journal of Educational Research, 107(3), 177-185. Retrieved from https://doi.org/10.1080/00220671.2013.807491

Fredricks, J. A., Blumenfeld, P. C., \& Paris, A. H. (2004). School engagement: Potential of the concept, state of the evidence. Review of Educational Research, 74(1), 59-109.

Henschke, J. A. (2009). A Productive decade of andragogy's history and philosophy 2000-2009. In V. Wang (Ed.) Assessing and Evaluating Adult Learning in Career and Technical Education. China: Zhejiang University Press.

Pearson, M. \& Smith. D. (1994). Debriefing in experience-based learning. In D. Boud, R. Keogh, \& D. Walke (Eds.). (2005). Reflection: Turning experience into learning. USA: Routledge.

Fenwick, T. \& Tennant, M. (2004). Understanding adult learners. In G. Foley (Ed.). Adult learning: adult education and training in a global era. England: Open University Press.

Jewczyn, N. (2010). Assessing mechanistic and organic organizational structures: measuring organizational uncertainty and determining an organization's proper structure. Journal of Business Management and Entrepreneurship 1(6). 